
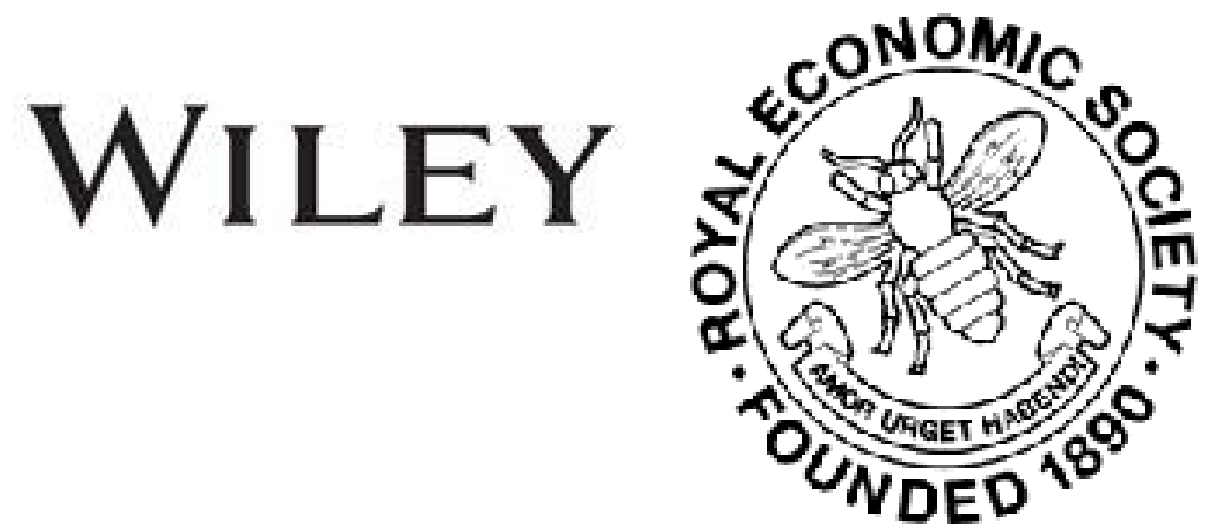

\title{
Canadian Currency
}

Author(s): J. B.

Source: The Economic Journal, Vol. 24, No. 94 (Jun., 1914), pp. 298-303

Published by: Wiley on behalf of the Royal Economic Society

Stable URL: http://www.jstor.org/stable/2222444

Accessed: 25-06-2016 02:38 UTC

Your use of the JSTOR archive indicates your acceptance of the Terms \& Conditions of Use, available at

http://about.jstor.org/terms

JSTOR is a not-for-profit service that helps scholars, researchers, and students discover, use, and build upon a wide range of content in a trusted digital archive. We use information technology and tools to increase productivity and facilitate new forms of scholarship. For more information about JSTOR, please contact support@jstor.org.

Wiley, Royal Economic Society are collaborating with JSTOR to digitize, preserve and extend access to The Economic Journal 


\section{NOTES AND MEMORANDA}

\section{Canadian Currency.}

THe Gold Exchange system of currency bids fair to become an accepted tenet of the Higher Criticism in Economics. Here in Canada we have come near to the system already, and a Canadian is tempted to compare East and West, in the light of Mr. Keynes' recent book on Indian Currency and Finance for the East, and for the West in the light of a report lately issued by the Finance Department of the Dominion Government on the "Public Accounts for the fiscal year ended March 31st, 1913."

Gold is the monarch of metals ; "they crowned him long ago" in England, and Canada is one of his loyal subjects. Canada has not been unhappy in her currency. Borrowing her coinage mainly from the United States and her banking mainly from Scotland, she has had no iron law of 1844 and for two centuries no greenbacks. Her history and her commercial relations are reflected in her recognition of gold sovereigns, gold eagles, and gold "beavers" as equally legal tender, as if gold were the essence, wherever coined. The equivalence of gold bars has not been recognised in legislation, at the date of writing. Only a very small part of the Government Reserve is in bars.

Nominally, then, we do not possess the Gold Exchange System; we do not have it in its ideal or Ricardian form. In theory ours is a Gold Standard with a Gold Currency.

But in practice it is the Gold Standard without the Gold Currency, "the only proper currency in the world" (Sir Edward Clouston, Indian Currency Committee, 1898, answ. 6778). The currency used every day by ordinary folk consists of silver and bronze tokens, from one cent to fifty cents, Dominion notes, and the notes of the twenty-four chartered banks. From the table given on page $\mathrm{xx}$. of the "Accounts" we can deduce that each Canadian in 1912 needed $\$ 2.29$ of Canadian silver coin, $14 \frac{1}{2}$ cents of bronze, and $\$ 3.14$ in the small Dominion notes of from 25 cents to 
four dollars in amount. This comparison alone shows a preference for paper, whatever allowance be made for the absence of a silver dollar to prefer. But, besides, there were wanted by each Canadian from $\$ 10$ to $\$ 12$ in the notes of the chartered banks. Canada is unlike British India; her education in the use of cheques as well as notes is fairly complete already; and there is no province where notes do not circulate and cheques are not used. The chief current money of the Canadian is papermoney. He has his irreducible minimum of metal tokens. As Canada becomes more crowided, the need of economy may be more felt and the use of bronze coins may become larger than it is. At present it is significantly small, and no country presents a greater contrast with British India, where the native looks closely at very small expenses and needs very small fractional coins by which to measure them.

The circulation of the bank-notes is given in the Dominion Gazette month by month, as the law directs. For the transactions of banks with banks there are large notes issued by the Dominion Government; and for the transactions of Government with the banks and for little else within the country there is need of gold coins. The Dominion notes, including the small ones to $\$ 4$, of which the Dominion Government has a monopoly, are really gold certificates, in whole or in large part. If in theory (see Mr. Keynes, p. 37) silver tokens are so, too, against the Government, yet in practice no silver tokens in Canada play any part like that of the rupee in India; and the claims of silver may be neglected. No part of the Government reserve is kept in silver. At the back of a circulation of Dominion notes, small and great, amounting on March 31st, 1913, to $\$ 112,101,885$, there was a reserve of $\$ 98,507,112$, in gold (Accounts, p. xv.).

We may call it 93 millions, for about $5 \frac{1}{2}$ are supposed to be held against the deposits of the Government Savings Banks, though apparently not "ear-marked" for that purpose. It is a sum equal to the whole "national debt" of Canada in the first year of Confederation (Accounts, p. 77) ; and, if it is dwarfed in amount by the 1,290 millions of the United States Treasury, it is a great sum for a population of hardly eight millions.

This large reserve is practically the only gold reserve in the country against anything in the nature of a panic. The amount of "current gold and subsidiary coin" held by the twenty-four chartered banks, according to their monthly returns, for example, on July 31st, 1913 (see Gazette of August 30th), was a good round sum, over 42 millions; but it may be called 
an actuarial reserve, an insurance against ordinary risks, the probable calls of a normal banking business. It is not a reserve against notes. In this country, a bank's notes are limited not by the gold it holds so much as by its paid-up capital; and its legal obligation in the matter of a reserve (so long as the issues are within the paid-up capital) is not to make it a certain proportion of anything else, but, whatever its size, to hold 40 per cent. of it in Dominion notes. The bank notes, the notes of the whole group of chartered banks, are guaranteed by a "circulation fund," to which the whole group contribute, as well as by priority of ranking as against other claims. The reserve is against ordinary liabilities other than notes; and it is not too large, 42 against 1,275 millions, especially as it is not in any case all gold. Sir E. B. Walker, in 1911, put the average amount held by banks in "specie and legal tenders" at 10 per cent. of the liabilities (address to Institute of Bankers, London, June 12th, 1911). Mr. Hartley Withers says that six leading English banks in 1908 held 18 per cent.; and, as he counts this high, perhaps he, too, would have been content with 10 (Meaning of Money, second edition, p. 264). A very different picture is presented when we look at the Government's reserve against Dominion notes.

Mr. Keynes (p. 156 of his Indian Currency) thinks it “extravagant to maintain a reserve adequate for all conceivable emergencies." He might quote Mr. Wicksteed's ingenious paradox: "The fact that a thing happens does not prove that it would have been wise to provide against it" (Common Sense of Political Economy, p. 120). Neither author would care to reduce a currency reserve to the proportions of an actuarial banking reserve. Allowance must be made for possible panics, and the question is, What panics and what allowance?

In Canada a panic throwing doubt on Dominion notes is not conceivable. A panic throwing doubt on the notes of all the twenty-four chartered banks at once is hardly conceivable, though just conceivable. A panic throwing doubt on the notes of one particular bank is not only conceivable, but has occurred. It might reasonably be asked if a gold reserve of 98 (or even 93) millions is absolutely necessary when the utmost drain upon it by the strongest bank in the Gazette's list would be about 21 millions? This is a little above the highest holding of Dominion notes by any one bank in any one month of 1913 .

The confidence of the Canadian people in their bank-notes exceeds that of the Scotch in their own. Sir Edward Clouston 
said (in effect) to the Committee on Indian Currency, 1898, (answ. 6787), that any hoarding there might be in Canada would be of bank-notes. Mr. Keynes remarks that in India the note circulation is less in the busy season, for the cultivators want silver in payment of their harvest (p. 53). On the contrary, when the Canadian farmers want good money for their grain, it is notes they have in mind; and the constant cry in summer is for more notes, whether Dominion notes or bank notes. This eager demand has carried the issues of the banks in the last half-dozen years to the full extent of the paid-up capital, beyond Sir Edward Clouston's expectations in 1898. The limit was not only reached, but by permission over-passed. The new Bank Act of 1913 enables it to be over-passed more regularly, on the orthodox plan of gold against notes. The Act permits the banks to establish a Central Gold Reserve of their own. Against this, they issue "dollar for dollar," according to their several deposits in it. Such issues may increase their prestige by showing they can dispense with the help of the Dominion Government. Otherwise it seems an unprofitable transaction.

The deposits in this new Reserve were in October, 1913, over 7 millions, in November over 8, in December $7 \frac{1}{2}$, and in January, 1914 , at the winding up of the harvest, no more than $3 \frac{1}{2}$, with only eight banks contributing.

Perhaps there is no country so seldom using gold coins in daily life and business that makes so much of gold coin as the invisible basis of currency. The result is a feeling of security not likely to be disturbed; but the price paid for it is an accumulation of barren metal beyond any conceivable need for the metal, except what would arise in a panic fear of the dissolution of civilised society, "the frame of things disjoint."

Mr. Keynes would probably advise a lightening of the burden by a resort to the money market (p. 156), in this case of New York and London. The Dominion Government might, like the banks, include short loans in their provision against liabilities in normal times; it might have liberty to lend from its reserves in abnormal times. But public opinion desires a Government to be even more cautious than a good bank, and would probably be against the adoption of the merely actuarial principle, or even an approach to it, in the matter of currency. The Canadian system seems Tikely to remain what it is, a form of the gold exchange system with one feature exaggerated.

It might be brought nearer to the ideal form by the more 
extensive substitution of bars for coin in the reserve. There could not be a replacement of the whole of the coin. Respect must be shown to the convenience of men of business dealing with New York, who will always from time to time have need of American eagles, legal tender in both countries, ready coined and at hand. Then there is the bankers' convenience. "We keep American gold against our foreign balances; the gold is really no use to us till it passes out of the country, giving us credit balances in other countries to draw against" (Clouston, loc. cit.). In the latter case bars would do as well. But, largely because they are legal tender in both countries, and the new Canadian pieces and sovereigns are legal tender in only one, the eagles and doubleeagles have been heaped up in the reserve in greater proportions than their rivals. Out of 98 millions, 93 are in gold pieces of the United States. The bars are not quite a quarter of a million; but for most purposes of foreign trade, bars with their fixed value in dollars would serve as well as coin. The process of striking would be saved; the labour of verification would be lessened, as well as the wear-and-tear involved in it. In Canada, as in India, "gold is brought to the Mint not to satisfy a demand for new gold currency, but because the owners of the gold wish to sell it" (Mr. Keynes, pp. 85, 86); and once they get its price, the sellers have no desire to see their article again. It is true that the tendency, so far as it goes, for the "over-production" of gold to increase prices will not be affected by the substitution of notes or certificates for gold coins, or by the manufacture of bars in place of coins. Nor would this last be at all incompatible with the "managed currency" that Sir Robert Giffen deplored and Prof. Irving Fisher desires. We should have our hands free to "manage" the currency or not, as we chose. It would but bring us an inch or two closer to the ideal gold exchange standard, and would save Government from making large quantities of unsaleable goods in the form of coins.

The Finance Department of the Dominion, on March 31st, 1913 , had in circulation notes to the value of $\$ 112,101,885$. Against this the law required a reserve in gold of

(1) Twenty-five per cent. of $\$ 30,000,000$, viz. $\ldots \ldots \ldots \ldots, \ldots 7,500,000$

(2) Dollar for dollar in the case of the notes exceeding

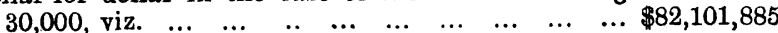

Besides

(3) Ten per cent. of the amount of Savings Banks'

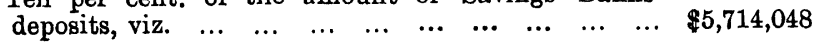

Total

$\$ 95,315,933$ 


\section{The actual holding was :-}

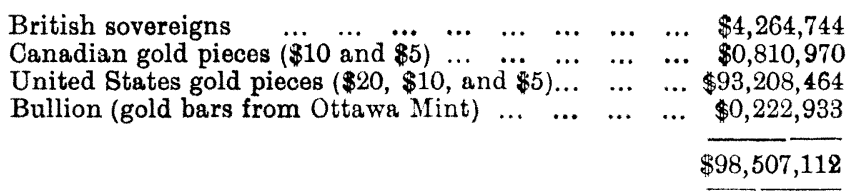

(Public Accounts, p. xv.)

The Daily Statement of the U.S. Treasury for January 2nd, 1914, furnished by the courtesy of the Director of the Mint, shows that on that date the Treasury held gold in its gold reserve and currency trust funds, in addition to $\$ 23,852,488$ gold coin held in the "General Fund" against ordinary Treasury liabilities, to the amount of $\$ 1,266,985,969$, against currency liabilities of $\$ 1,116,985,969$ in gold certificates, $\$ 2,555,000$ in Treasury notes, and $\$ 346,681,016$ in United States notes, total, $\$ 1,466,221,985$. The silver certificates $(\$ 489,570,000)$ have their own silver reserve. They have no parallel in Canada.

Ottawa, J. B.

January, 1914.

\section{A Letter from Japan-Japanese Finance, 1910-1913.}

(1) General Remarks.

As I mentioned in my last letter, ${ }^{1}$ an unusually low rate of interest and a succession of debenture issues were the most striking features of 1910. During the first half of 1911 also debenture issues continued to appear ; and owing to the redemption of a vast amount of exchequer bonds at the end of May and to a large interest payment of national loans at the end of June, the money market kept up the long-continued ease to the middle of that year. On account of a large importation of merchandise in anticipation of the new tariff, the excess of imports over exports was strikingly increased, and by the end of July the excess was more than one hundred and twenty million yen. A low rate of interest encouraged fresh enterprises, and the importation of machinery and raw materials increased yet further, while the good crop of rice expected the autumn following greatly stimulated the purchasing power of the farmers. The prospects of the business world were, therefore, very promising. With the progress, however, of the troubles in Morocco, the money markets of Europe became very firm, while the disturbances in

1 See Economic Jourana, December, 1910, in continuation of previous letters. 